\title{
Whole body and muscle energy metabolism in preruminant calves: effects of nutrient synchrony and physical activity
}

\author{
Joost J. G. C. van den Borne ${ }^{1 *}$, Jean-François Hocquette ${ }^{2}$, Martin W. A. Verstegen ${ }^{1}$ and Walter J. \\ J. Gerrits ${ }^{1}$ \\ ${ }^{1}$ Animal Nutrition Group, Department of Animal Sciences, Wageningen University, P.O. Box 338, 6700 AH Wageningen, The \\ Netherlands \\ ${ }^{2}$ Unité de Recherches sur les Herbivores, INRA, Clermont-Ferrand/Theix, 63122 Saint-Genès-Champanelle, France
}

(Received 13 June 2006 - Revised 6 November 2006 - Accepted 10 November 2006)

\begin{abstract}
The effects of asynchronous availability of amino acids and glucose on muscle composition and enzyme activities in skeletal muscle were studied in preruminant calves. It was hypothesized that decreased oxidative enzyme activities in muscle would explain a decreased whole body heat production with decreasing nutrient synchrony. Preruminant calves were assigned to one of six degrees of nutrient synchrony, step-wise separating the intake of protein and lactose over the two daily meals. Calves at the most synchronous treatment received two identical meals daily. At the most asynchronous treatment, $85 \%$ of the daily protein and $20 \%$ of the daily lactose supply were fed in one meal and the remainder in the other meal. Daily intakes of all dietary ingredients were identical for all treatments. Oxidative enzyme activities and fat content increased with decreasing nutrient synchrony in M. Rectus Abdominis (RA), but not in M. Semitendinosus. Cytochrome-c-oxidase activity was positively correlated with fat content in RA $(r 0.49 ; P<0.01)$. Oxidative enzyme activities in both muscles were not correlated with average daily heat production, but citrate synthase activity in RA was positively correlated $(P<0.01)$ with the circadian amplitude $(r 0.53)$ and maximum $(r 0.61)$ of heat production associated with physical activity. In conclusion, this study indicates that muscle energy stores are regulated by nutrient synchrony. The lack of correlation between muscle oxidative enzyme activities and average daily heat production was in contrast with findings in human subjects. Therefore, oxidative enzyme activity in muscle should not be used as an indicator for whole body heat production in growing calves.
\end{abstract}

Energy metabolism: Muscle: Nutrient synchrony: Physical activity

Daily nutrient intake has been correlated with muscle enzyme activities in animals (Cassar-Malek et al. 2004) and man (Helge \& Kiens, 1997), and with intramuscular fat and glycogen contents in animals (Pethick \& Rowe, 1996; Gondret et al. 2000). Regulation of muscle oxidative enzyme activities and muscle composition also depends on the supply of individual macronutrients (Hocquette et al. 1998; Geelen et al. 2001; Gondret \& Lebret, 2002). Apart from variation in daily nutrient supply, within-day variation in the supply of different nutrients (i.e. synchrony) may induce these effects. Asynchronous absorption patterns can be induced by either a separated intake of protein and carbohydrates in time (e.g. dissociated diets) or by supplying ingredients with different kinetics of digestion and absorption. In preruminants, for example, asynchronous absorption of glucose and amino acids may result from differences in passage behaviour of clotting $v$. non-clotting dietary ingredients (Guilloteau et al. 1986; Verdonk et al. 1999). Applying a theoretical approach, we separated the intake of glucose and amino acids within the day (i.e. across meals) in heavy preruminant calves (Van den Borne et al. 2006b). Surprisingly, and in contrast to similar investigations in pigs (JJGC Van den Borne, JW Schrama, MJW Heetkamp, MWA Verstegen and WJJ Gerrits, unpublished results), increased separation of the amino acid and glucose availability within a day decreased whole body heat production $(-9 \%)$, and increased whole body fat deposition $(+59 \%)$, in heavy preruminant calves (Van den Borne et al. 2006b). Muscle energy metabolism may contribute to these changes as it accounts for about $20 \%$ of the daily heat production in growing farm animals (Ortigues et al. 1995). Therefore, muscle energy metabolism may help to spare energy in case of an asynchronous supply of protein and lactose. Effects of nutrient synchrony on the energy metabolism and composition of muscles may also have implications for muscle function, meat quality and development of metabolic disorders in calves.

The regulation of muscle energy metabolism is well documented (e.g. Hocquette et al. 1998). In non-growing man, oxidative enzyme activities in muscle are positively correlated with whole body heat production (Zurlo et al. 1994; Doucet

\footnotetext{
Abbreviations: BW, body weight; $\mathrm{COX}$, cytochrome-c-oxidase; $\mathrm{CS}$, citrate synthase; $\mathrm{H}_{\text {act }}$, heat production associated with physical activity; $\mathrm{H}_{\text {cor }}$, heat production corrected for physical activity; $\mathrm{H}_{\mathrm{tot}}$, total heat production; $\mathrm{LDH}$, lactate dehydrogenase; $\mathrm{ME}_{\mathrm{m}}$, metabolizable energy requirements for maintenance; RA, M. Rectus Abdominis; SEQ, meal sequence; ST, M. Semitendinosus; SYN, degree of nutrient synchrony.

* Corresponding author: Dr Joost van den Borne, fax +31317 4842 60, email joost.vandenborne@wur.nl
} 
et al. 2003). It is not known if a similar relationship exists in growing animals and if increased oxidative enzyme activities in muscle are associated with increased whole body heat production. In addition, it is unknown to what extent the demand for energy in muscle, i.e. for physical activity, drives the activity of the enzymes and hence regulates muscle energy metabolism in farm animals.

The aim of this study was therefore to gain insight in the regulation of whole body heat production by assessing the effects of nutrient synchrony and physical activity on muscle enzyme activities and muscle composition in heavy preruminant calves. Results on whole body protein and energy utilization have been presented elsewhere (Van den Borne et al. $2006 b$ ). It is hypothesized that oxidative enzyme activities decrease and intramuscular fat content increases with decreasing nutrient synchrony in preruminant calves. Oxidative enzyme activities in skeletal muscle were expected to correlate with whole body heat production.

\section{Materials and methods}

\section{Animals, housing and experimental treatments}

Thirty-six male, preruminant calves of the Holstein Friesian breed were used. The experimental treatments consisted of six degrees of nutrient synchrony (SYN 1 to 6) at each of two meal sequences (SEQ A and B) in a $6 \times 2$ factorial arrangement. The experiment was originally designed to study effects of SYN and SEQ on nutrient utilization (Van den Borne et al. 2006b). Two identical respiration chambers were available and calves were studied in eighteen trials of two calves each. Individual calves of approximately $130 \mathrm{~kg}$ body weight (BW) were assigned to an experimental treatment. The degree of nutrient synchrony was varied by a step-wise exchange of protein and lactose between the two daily meals (on a calculated digestible energy basis) which resulted in an equal distribution of digestible energy intake within a day (Table 1). Calves at SYN 1 received two identical meals daily. Calves at the most asynchronous treatment, SYN 6 , received $85 \%$ of the daily protein supply in one meal and the remaining $15 \%$ in the other meal. A high protein meal was fed in the morning and a high lactose meal was fed in

Table 1. Experimental treatments; division of the nutrient intake $(\mathrm{g} / \mathrm{kg}$ $\mathrm{BW}^{0.75}$ ) over two daily meals

\begin{tabular}{lrrrrrr}
\hline Treatment (SYN)... & 1 & 2 & 3 & 4 & 5 & 6 \\
\cline { 2 - 7 } CON & \multicolumn{1}{c}{50} & 57 & 64 & 71 & 78 & 85 \\
\hline Morning meal ${ }^{*}(06.00 \mathrm{~h})$ & & & & & & \\
$\quad$ Protein & 4.6 & 5.3 & 5.9 & 6.5 & 7.1 & 7.7 \\
$\quad$ Lactose & 10.0 & 8.9 & 7.8 & 6.7 & 5.6 & 4.5 \\
$\quad$ Fat & 4.6 & 4.6 & 4.6 & 4.6 & 4.6 & 4.6 \\
Evening meal (18.00 h) & & & & & & \\
$\quad$ Protein & 4.6 & 4.0 & 3.4 & 2.8 & 2.2 & 1.6 \\
$\quad$ Lactose & 10.0 & 11.1 & 12.2 & 13.4 & 14.5 & 15.6 \\
$\quad$ Fat & 4.6 & 4.5 & 4.5 & 4.5 & 4.5 & 4.5 \\
\hline
\end{tabular}

CON, contribution of the high protein meal to the daily protein supply $(50 \%=$ two identical, balanced meals; $100 \%=$ all daily protein in one meal); SYN, degree of nutrient synchrony.

*Treatments are presented for meal sequence A. For meal sequence B, the nutrient intake in the morning and evening meal was reversed. the evening for calves at SEQ A. For calves at SEQ B, this sequence was reversed. Allocation of calves to SYN and SEQ was balanced in time across trials.

Calves were fed the experimental diets for five weeks. During the first four weeks of study, calves were individually housed in cages $(1.85 \times 0.75 \mathrm{~m})$ in a climate-controlled stable. Then they were moved to the respiration chambers where whole body heat production was measured during one week. The experiment complied with the Dutch law regarding the use of experimental animals.

\section{Diets and feeding}

Calves were fed according to their metabolic $\mathrm{BW}\left(\mathrm{BW}^{0.75}\right)$, adjusted daily for a projected daily gain of $1000 \mathrm{~g}$. Metabolizable energy requirements for maintenance $\left(\mathrm{ME}_{\mathrm{m}}\right)$ were assumed to be $460 \mathrm{~kJ} / \mathrm{d}$ per $\mathrm{kg} \mathrm{BW}^{075}$ (Van Es et al. 1967; Gerrits et al. 1996), and the feeding level was $2.0 \times \mathrm{ME}_{\mathrm{m}}$. Two basal milk replacers were produced for the most asynchronous treatment (SYN 6). All other experimental treatments were realized by mixing the basal milk replacers in the appropriate ratio to create the experimental contrast presented in Table 1. The detailed nutrient and ingredient composition of the basal milk replacers are given by Van den Borne et al. (2006b). Briefly, diets included whey protein concentrate, lactose and coconut and soya oil as main ingredients. Diets provided on a daily basis $20.5 \%$ crude protein, $20.8 \%$ crude fat and $44.9 \%$ lactose. Daily intakes of all nutrients and dietary ingredients were similar between treatments. Milk replacer was reconstituted with water (140 g/l) and supplied at a temperature of about $40^{\circ} \mathrm{C}$ in a bucket. Roughage was not provided. Calves were fed individually at $06.00 \mathrm{~h}$ and $18.00 \mathrm{~h}$, and were allowed $15 \mathrm{~min}$ to consume the meal. Feed intake was measured twice daily and BW was measured weekly throughout the experiment. Average daily gain and feed conversion ratio were calculated over the 5 week experimental period.

\section{Measurement of whole body heat production and physical activity}

During the fifth week of the study, gas exchange $\left(\mathrm{O}_{2}, \mathrm{CO}_{2}\right.$ and $\mathrm{CH}_{4}$ ) was continuously measured during $7 \mathrm{~d}$ in 6 min intervals by indirect calorimetry for estimation of whole body heat production. From the gaseous exchange, heat production $\left(\mathrm{H}_{\mathrm{tot}}\right)$ was calculated according to the formula of Brouwer (1965) and the RQ was calculated as the $\mathrm{CO}_{2}$ production divided by the $\mathrm{O}_{2}$ consumption. Posture of calves was measured every minute by IR beam interruption. Physical activity was recorded with a radar-Doppler device according to the method described by Wenk \& Van Es (1976). From these measurements, heat production associated with physical activity $\left(\mathrm{H}_{\mathrm{act}}\right)$ and heat production corrected for physical activity $\left(\mathrm{H}_{\text {cor }}\right)$ were separately estimated (Van den Borne et al. 2006a). The kinetics of whole body heat production were described by calculation of the hourly means of $\mathrm{H}_{\text {tot }}$, $\mathrm{H}_{\text {cor }}$ and $\mathrm{H}_{\mathrm{act}}$ for each calf. The circadian maximum and minimum were defined for each calf as the highest and lowest hourly means within a day, respectively. The amplitudes of $\mathrm{H}_{\text {tot }}, \mathrm{H}_{\text {cor }}$ and $\mathrm{H}_{\text {act }}$ were subsequently calculated as the difference between the circadian maximum and minimum for each 
calf. For calculating circadian means of heat production by the formula of Brouwer (1965), the nitrogen excretion was assumed to be constant throughout the day.

\section{Measurement of muscle composition and enzyme activities}

After five weeks on the experimental treatment, calves were transported to the slaughterhouse $(20 \mathrm{~min})$ and killed at $13.00 \mathrm{~h}$ (i.e. $7 \mathrm{~h}$ after the morning meal) by stunning and exsanguination. Within $15 \mathrm{~min}$ post-slaughtering, samples of the M. Rectus Abdominis (RA; oxido-glycolytic muscle) and M. Semitendinosus (ST; glycolytic muscle) were removed. The samples of skeletal muscle were immediately trimmed of visible fat and connective tissue. Samples were then cut into pieces, immediately frozen in liquid $\mathrm{N}_{2}$ and stored at $-80^{\circ} \mathrm{C}$ pending analyses. Samples for crude fat analysis (about $30 \mathrm{~g}$ for each muscle) were not frozen in liquid $\mathrm{N}_{2}$, but ice-chilled and subsequently stored at $-20^{\circ} \mathrm{C}$ pending analyses.

Protein (Bradford, 1976) and DNA (Labarca \& Paigen, 1980) contents were measured in muscle homogenates. Activity of the oxidative enzyme citrate synthase (CS; EC 4.1.3.7), which is involved in the substrate flux through the tricarboxylic acid cycle, was determined in sonicated homogenates by measuring the rate of initial reaction at $412 \mathrm{~nm}$ by means of the DTNB (5.5'-dithiobis(2-nitrobenzoate)) method as described by Shepherd \& Garland (1969). Activity of the oxidative enzyme cytochrome-c-oxidase (COX; EC 1.9.3.1), which is involved in the substrate flux through the respiratory chain, was determined in sonicated homogenates by measuring the oxidation of reduced cytochrome- $c$ as described by Van Hinsberg et al. (1978). Activities of CS and COX were expressed in $\mu \mathrm{mol}$ CoA liberated per min per $\mathrm{g}$ protein and in $\mu \mathrm{mol}$ cytochrome- $c$ oxidized per min per $\mathrm{g}$ protein at $25^{\circ} \mathrm{C}$ respectively. Activity of the glycolytic enzyme lactate dehydrogenase (LDH; EC 1.1.1.2.7), which catalyzes the formation of lactate from pyruvate, was determined as described by Ansay (1974). LDH activity was expressed in $\mu \mathrm{mol}$ NADH oxidized per min per $\mathrm{g}$ protein. Glycogen content was measured by the method of Carroll et al. (1955). Briefly, glycogen was extracted from the tissue by homogenization with $5 \%$ trichloroacetic acid solution, precipitated from the extract by $95 \%$ ethanol and determined with the anthrone reagent in a colorimeter at $620 \mathrm{~nm}$. Fat content was measured in muscle tissue after freeze-drying according to ISO 6492 (International Organization for Standardization, 1999). Ratios for CS:LDH, COX:LDH (relative enzyme activities), protein:DNA (indicator for muscle fibre size) and COX:CS (indicator for the biochemical properties of the mitochondria) were calculated.

\section{Statistical analysis}

The effects of nutrient synchrony and the interaction between nutrient synchrony and meal sequence on muscle traits and whole body energy metabolism traits were analysed by linear regression analysis, using the general linear model procedure of the SAS statistical software package version 9.1 (Statistical Analysis Systems Institute, Cary, NC, USA). The degree of nutrient synchrony was included as a regressor
(Default 1).

$$
Y_{i j}=\mu+\beta_{1} \times X_{j}+\beta_{2 i} \times S_{i} X_{j}+\varepsilon_{i j},
$$

where $Y_{i j}=$ dependent variable over the whole period, $\mu=$ average intercept, $\beta_{1}=$ effect of degree of nutrient synchrony, expressed as percentage of the daily protein intake in the high protein meal, $\beta_{2 i}=$ interaction between degree of nutrient synchrony and meal sequence $i, S_{i}=$ fixed effect of meal sequence $i, X_{j}=$ degree of nutrient synchrony (expressed as percentage of the daily protein intake in the high protein meal) for calf $j, \varepsilon_{i j}=$ error term, $i=1,2$, and $j=1, \ldots, 18$.

Pearson correlation coefficients were calculated for relationships between muscle energy metabolism traits within each muscle, for each trait between the two muscles and between muscle energy metabolism traits and whole body energy metabolism traits. Traits for the two muscles were compared by pairwise comparisons.

\section{Results}

Animal performance

Two calves were excluded from analysis, because of feed refusals or illness. The initial BW of the calves was 128 (SEM 1.7 ) $\mathrm{kg}$ and average daily gain during the 5 week experimental period was 885 (SEM 27.1) g. Average daily gain was lower $(P<0.05)$ for calves at SYN 5 and $6(729$ and $815 \mathrm{~g}$ respectively) than for calves at SYN 1-4. Calves at SYN $1-4$ had a similar daily gain (on average $945 \mathrm{~g}$ ). Feed intake did not differ between treatments and consequently the feed to gain ratio was higher $(P<0.01)$ for calves at SYN 5 and 6 (2.56 and 2.48 respectively) than for calves at the other treatments (on average 2.02). However, calves at the two most asynchronous treatments had a lower nutrient digestibility. The consequently lower digestible nutrient intake in calves at SYN 5 and 6 complicated interpretation of the results from SYN 1 to 6 . Linear regression was therefore also performed for SYN 1 to 4 (n 22) separately, because calves at those treatments had identical digestible nutrient intakes.

\section{Muscle enzyme activities}

In RA, activities of COX and CS increased $(P=0.048)$ and tended to increase $(P=0.075)$, respectively, with decreasing nutrient synchrony (SYN 1-4; Table 2). Ratios of enzyme activities were not affected by nutrient synchrony. In ST, enzyme activities were not affected by nutrient synchrony (Table 3). The sequence of the high protein and high carbohydrate meals did not affect enzyme activities.

\section{Muscle composition}

Intramuscular fat content increased in RA $(P=0.037)$ with decreasing nutrient synchrony at an identical digestible nutrient intake (Table 2), but nutrient synchrony did not affect intramuscular fat content in ST (Table 3). The fat content was substantially higher $(P<0.001)$ in RA $(18.9 \mathrm{mg} / \mathrm{g}$ tissue $)$ than in ST $(6.5 \mathrm{mg} / \mathrm{g}$ tissue). The sequence of the high protein and high carbohydrate meals did not affect intramuscular fat content. 
Table 2. Effects of nutrient synchrony on muscle enzyme activities and muscle composition in $M$. Rectus Abdominis of heavy preruminant calves (Values are means for treatments with their standard errors; $n 5$ per treatment for SYN 1 and 2 , and $n 6$ per treatment for SYN 3-6)

\begin{tabular}{|c|c|c|c|c|c|c|c|c|c|c|c|c|}
\hline \multirow{2}{*}{$\begin{array}{l}\text { Treatment (SYN)... } \\
\text { CON }\end{array}$} & \multirow{2}{*}{$\frac{1}{50}$} & \multirow{2}{*}{$\begin{array}{c}2 \\
57\end{array}$} & \multirow{2}{*}{$\begin{array}{c}3 \\
64\end{array}$} & \multirow{2}{*}{$\begin{array}{c}4 \\
71\end{array}$} & \multirow{2}{*}{$\begin{array}{c}5 \\
78\end{array}$} & \multirow{2}{*}{$\frac{6}{85}$} & \multicolumn{3}{|c|}{ SYN 1-6 } & \multicolumn{3}{|c|}{ SYN 1-4 } \\
\hline & & & & & & & SEM & $b^{*}$ & $P$ valuet & SEM & $b$ & $P$ value \\
\hline \multicolumn{13}{|c|}{ Enzyme activity ( $\mu \mathrm{mol} / \mathrm{g}$ protein per min) } \\
\hline LDH & 4317 & 4269 & 4502 & 4447 & 4358 & 4076 & $286 \cdot 2$ & $-4.5 \times 10^{-3}$ & 0.673 & 344.4 & $8.7 \times 10^{-3}$ & 0.710 \\
\hline $\operatorname{cox}$ & 119 & 97 & 119 & 154 & 121 & 99 & $13 \cdot 7$ & $0.2 \times 10^{-4}$ & 0.960 & $14 \cdot 1$ & $2.0 \times 10^{-3}$ & 0.048 \\
\hline CS & 54 & 52 & 57 & 67 & 58 & 51 & $5 \cdot 3$ & $0.4 \times 10^{-4}$ & 0.850 & 5.0 & $0.7 \times 10^{-3}$ & 0.075 \\
\hline \multicolumn{13}{|l|}{ Relative enzyme activity } \\
\hline COX:CS & $2 \cdot 22$ & 1.87 & $2 \cdot 16$ & $2 \cdot 70$ & $2 \cdot 33$ & 2.00 & 0.321 & $2.3 \times 10^{-3}$ & 0.849 & 0.299 & 0.01 & 0.499 \\
\hline COX:LDH, $\times 10^{-3}$ & $27 \cdot 8$ & 24.6 & $27 \cdot 7$ & $35 \cdot 3$ & 28.4 & $24 \cdot 2$ & 3.92 & $2.1 \times 10^{-6}$ & 0.989 & 4.32 & $0.4 \times 10^{-3}$ & 0.191 \\
\hline CS:LDH, $\times 10^{-3}$ & $12 \cdot 4$ & $12 \cdot 8$ & $12 \cdot 9$ & $15 \cdot 9$ & $13 \cdot 8$ & $12 \cdot 3$ & 1.53 & $0.2 \times 10^{-4}$ & 0.728 & 1.48 & $0.2 \times 10^{-3}$ & $0 \cdot 180$ \\
\hline \multicolumn{13}{|l|}{ Muscle composition } \\
\hline Glycogen(mg/g fresh tissue)‡ & 5.9 & $7 \cdot 6$ & $6 \cdot 2$ & $6 \cdot 0$ & 5.5 & $6 \cdot 1$ & $1 \cdot 14$ & -0.02 & 0.630 & $1 \cdot 25$ & $-9.0 \times 10^{-3}$ & 0.907 \\
\hline Fat (mg/g fresh tissue) & $16 \cdot 3$ & 13.5 & 21.9 & 23.9 & $16 \cdot 3$ & 13.7 & 2.46 & -0.03 & 0.802 & 2.43 & 0.44 & 0.037 \\
\hline Protein (mg/g fresh tissue) & 165 & 175 & 170 & 158 & 162 & 172 & $7 \cdot 0$ & -0.07 & 0.764 & $7 \cdot 7$ & -0.45 & 0.391 \\
\hline DNA ( $\mu \mathrm{g} / \mathrm{g}$ fresh tissue) & 1881 & 1972 & 2017 & 1996 & 1977 & 1989 & $55 \cdot 1$ & 1.95 & 0.309 & 47.9 & $5 \cdot 75$ & 0.088 \\
\hline Protein:DNA (mg/mg) & $88 \cdot 1$ & $88 \cdot 8$ & $84 \cdot 8$ & $79 \cdot 4$ & $82 \cdot 3$ & $87 \cdot 0$ & 4.39 & $-0.1 \times 10^{-3}$ & 0.435 & 4.92 & $-0.5 \times 10^{-3}$ & $0 \cdot 140$ \\
\hline
\end{tabular}

CON, contribution of the high protein meal to the daily protein supply $(50 \%=$ two identical, balanced meals; $100 \%=$ all daily protein in one meal); SYN, degree of nutrient synchrony; LDH, lactate dehydrogenase; COX, cytochrome $c$-oxidase; CS, citrate synthase.

"Regression coefficient $(y=a+b \times x)$, representing the change in response parameter per \% increase of the contribution of the high protein meal to the daily protein supply.

†Probability for test if the regression coefficient $(b)$ equals 0 . Effects of meal sequence and interactions between meal sequence and degree of nutrient synchrony were non-significant and were therefore excluded from the model. $\ddagger$ An interaction between $\mathrm{CON}$ and the meal sequence on muscle glycogen content was found $(P=0.023)$.

Table 3. Effects of nutrient synchrony on muscle enzyme activities and muscle composition in M. Semitendinosus of heavy preruminant calves (Values are means for treatments with their standard errors; $n 5$ per treatment for SYN 1 and 2 , and $n 6$ per treatment for SYN 3-6)

\begin{tabular}{|c|c|c|c|c|c|c|c|c|c|c|c|c|}
\hline \multirow{2}{*}{$\begin{array}{l}\text { Treatment }(\mathrm{SYN}) \ldots \\
\text { CON }\end{array}$} & \multirow{2}{*}{$\frac{1}{50}$} & \multirow{2}{*}{$\begin{array}{c}2 \\
57\end{array}$} & \multirow{2}{*}{$\begin{array}{c}3 \\
64\end{array}$} & \multirow{2}{*}{$\begin{array}{c}4 \\
71\end{array}$} & \multirow{2}{*}{$\begin{array}{c}5 \\
78\end{array}$} & \multirow{2}{*}{$\frac{6}{85}$} & \multicolumn{3}{|c|}{ SYN $1-6$} & \multicolumn{3}{|c|}{ SYN $1-4$} \\
\hline & & & & & & & SEM & $b^{\star}$ & $P$ value $†$ & SEM & $b$ & $P$ value \\
\hline \multicolumn{13}{|c|}{ Enzyme activity ( $\mu \mathrm{mol} / \mathrm{g}$ protein per min) } \\
\hline LDH & 4167 & 4618 & 4500 & 4738 & 4381 & 4562 & $242 \cdot 2$ & $5.2 \times 10^{-3}$ & 0.543 & 272.9 & $0.2 \times 10^{-4}$ & 0.240 \\
\hline $\operatorname{cox}$ & 113 & 94 & 78 & 103 & 90 & 96 & $12 \cdot 7$ & $-0.2 \times 10^{-3}$ & 0.544 & $12 \cdot 8$ & $-0.5 \times 10^{-3}$ & 0.525 \\
\hline CS & 46 & 53 & 43 & 61 & 54 & 58 & 4.9 & $0.3 \times 10^{-3}$ & 0.095 & 5.4 & $0.5 \times 10^{-3}$ & 0.166 \\
\hline \multicolumn{13}{|l|}{ Relative enzyme activity } \\
\hline COX:CS & 2.51 & 1.80 & 2.04 & 1.72 & 1.68 & 1.62 & 0.264 & -0.02 & 0.051 & 0.326 & -0.03 & 0.199 \\
\hline $\mathrm{COX}: \mathrm{LDH}, \times 10^{-3}$ & 29.4 & 21.2 & $17 \cdot 8$ & 22.0 & 20.9 & 21.6 & 3.91 & $-0.1 \times 10^{-3}$ & 0.347 & 4.14 & $-0.3 \times 10^{-3}$ & 0.267 \\
\hline $\mathrm{CS}: \mathrm{LDH}, \times 10^{-3}$ & 11.5 & 11.8 & 9.7 & 13.1 & $12 \cdot 4$ & $12 \cdot 8$ & 1.37 & $0.1 \times 10^{-3}$ & 0.311 & 1.53 & $0.6 \times 10^{-4}$ & 0.533 \\
\hline \multicolumn{13}{|l|}{ Muscle composition } \\
\hline Glycogen (mg/g fresh tissue)‡ & 6.7 & $6 \cdot 6$ & 8.2 & 6.4 & $6 \cdot 8$ & $6 \cdot 8$ & 1.06 & $-1.4 \times 10^{-3}$ & 0.969 & $1 \cdot 14$ & $-0.3 \times 10^{-3}$ & 0.881 \\
\hline Fat (mg/g fresh tissue) & $5 \cdot 6$ & 5.4 & 7.4 & 7.6 & $6 \cdot 1$ & 6.0 & 0.98 & 0.01 & 0.717 & 1.19 & 0.12 & 0.166 \\
\hline Protein (mg/g fresh tissue) & 177 & 171 & 171 & 166 & 172 & 175 & 5.5 & -0.04 & 0.841 & 6.9 & -0.42 & 0.283 \\
\hline DNA ( $\mu \mathrm{g} / \mathrm{g}$ fresh tissue) & 1964 & 1880 & 1908 & 1950 & 1944 & 1844 & 80.8 & -1.57 & 0.594 & 84.9 & -0.74 & 0.889 \\
\hline Protein:DNA $(\mathrm{mg} / \mathrm{mg})$ & 92.7 & 93.1 & 89.6 & 85.9 & 90.2 & 94.8 & 5.69 & $0.1 \times 10^{-4}$ & 0.961 & 6.62 & 0.01 & 0.475 \\
\hline
\end{tabular}

$\mathrm{CON}$, contribution of the high protein meal to the daily protein supply ( $50 \%=$ two identical, balanced meals; $100 \%$ = all daily protein in one meal); SYN, degree of nutrient synchrony; $\mathrm{LDH}$, lactate dehydrogenase; $\mathrm{COX}$, cytochrome- $\mathrm{C}$-oxidase; $\mathrm{CS}$, citratesynthase.

Regression coefficient $(y=a+b \times x)$, representing the change in response parameter per \% increase of the contribution of the high protein meal to the daily protein supply.

$\dagger$ Probability for test if the regression coefficient $(b)$ equals 0 . Effects of meal sequence and interactions between meal sequence and degree of nutrient synchrony were non-significant and were therefore excluded from the model. $\ddagger$ An interaction between $\mathrm{CON}$ and the meal sequence on muscle glycogen content was found $(P=0.007)$. 
Glycogen content in both muscles was not affected by nutrient synchrony (Tables 2 and 3), but a positive correlation between glycogen content in RA and ST was found ( $r 0.72$; $P<0 \cdot 001)$. Glycogen content averaged $6 \cdot 24 \mathrm{mg} / \mathrm{g}$ in RA and $7.01 \mathrm{mg} / \mathrm{g}$ in ST. An interaction between SEQ and SYN was found for intramuscular glycogen content in both muscles $(P<0.05)$, indicating that glycogen content was higher after feeding the high protein diet than after the high lactose diet. The difference in glycogen content between meal sequences was more pronounced at SYN $2(3.08 \mathrm{mg} / \mathrm{g}$ in RA and $6.08 \mathrm{mg} / \mathrm{g}$ in ST) and SYN $3(4.63 \mathrm{mg} / \mathrm{g}$ in RA and $4.96 \mathrm{mg} /$ $\mathrm{g}$ in ST) than at the other treatments.

\section{Whole body heat production}

Average heat production and $\mathrm{H}_{\text {cor }}$ decreased with decreasing nutrient synchrony $(P<0.05)$, while the RQ increased $(P=0.028$; Table 4). A detailed description of whole body energy partitioning and protein deposition is presented and discussed elsewhere (Van den Borne et al. 2006b). The maxima of the circadian patterns of $\mathrm{H}_{\text {tot }}$ and $\mathrm{H}_{\text {cor }}$ decreased with decreasing nutrient synchrony $(P<0 \cdot 05)$, but the maximum of the circadian pattern of $\mathrm{H}_{\mathrm{act}}$ was not affected by nutrient synchrony. The amplitudes of the circadian patterns of $\mathrm{H}_{\text {tot }}, \mathrm{H}_{\text {cor }}$ and $\mathrm{H}_{\mathrm{act}}$ were not affected by SYN. The sequence of the high protein and high carbohydrate meals did not affect any of the traits of whole body energy metabolism.

\section{Correlations within muscle}

In both muscles, $\mathrm{CS}$ and $\mathrm{COX}$ activities were positively correlated $(r \quad 0.35-0.36 ; P<0.05)$. Intramuscular fat content showed a positive correlation $(r 0.49 ; P<0.01)$ with $\mathrm{COX}$ (and COX:LDH) in RA (data not shown).

\section{Correlations between muscle energy metabolism and whole body energy metabolism}

The decreased $\mathrm{H}_{\text {tot }}$ and $\mathrm{H}_{\text {cor }}$ with decreasing nutrient synchrony did not correspond with the increased (or unaffected) oxidative enzyme activities in muscle. In accordance, simple correlation analysis showed that average $\mathrm{H}_{\text {tot }}, \mathrm{H}_{\text {cor }}$ and $\mathrm{H}_{\mathrm{act}}$ were not correlated with enzyme activities in RA (Table 5) and ST (data not shown). Intramuscular fat content in RA was negatively correlated with average $\mathrm{H}_{\text {tot }}$ and $\mathrm{H}_{\text {cor }}$.

The maximum of $\mathrm{H}_{\text {act }}$ and the amplitude of $\mathrm{H}_{\text {tot }}$ and $\mathrm{H}_{\text {act }}$ increased with increasing CS activity in RA in preruminant calves, resulting in positive correlations (Table 5). In ST, oxidative enzyme activities were not related to the maxima and amplitudes of heat production traits (data not shown).

\section{Discussion}

\section{Animal performance}

Feeding more than $71 \%$ of the daily protein in one meal and more than $68 \%$ of the daily lactose in the other one (i.e. SYN 5-6) induced diarrhoea, which was indicated by a lower faecal dry matter content, a lower faecal $\mathrm{pH}$ and a lower nutrient digestibility (Van den Borne et al. 2006b). The lower daily gain and higher feed to gain ratio for calves at SYN 5 and 6 were therefore likely due to a decreased digestible nutrient intake. Comparison of calves at SYN 1-4 allows studying the effects of nutrient synchrony at identical intakes of digestible nutrients. Therefore, this discussion focuses on treatments SYN 1-4.

\section{Effects of nutrient synchrony on muscle enzyme activities}

Although the quantity (Brandstetter et al. 1998; Cassar-Malek et al. 2004) and the composition (Helge \& Kiens, 1997; Geelen et al. 2001; Cuvelier et al. 2006) of the daily feed supply are known to affect oxidative and glycolytic enzyme activities in muscles, this study is one of the first to describe the effect of within-day distribution of nutrient availability on muscle metabolism. Ortigues-Marty et al. (2003) found increased oxidative enzyme activities in muscle (ST) of preruminant calves when skimmed milk protein was replaced by soluble wheat and whey proteins. Feeding soluble wheat and whey proteins resulted in larger circadian fluctuations of the amino acid availability compared with skimmed milk protein. Therefore, it was suggested that a transiently high amino acid availability may require an increased capacity of oxidative enzymes in muscle to provide energy for protein synthesis when amino acids are available (Ortigues-Marty et al. 2003). However, potential reasons for the affected oxidative capacity in the study of Ortigues-Marty et al. (2003) also include a lower intake of the skimmed milk diet than of the wheat and whey protein diet and the use of different dietary ingredients with different kinetics of fatty acid absorption (Petit et al. 1988; Cruywagen et al. 1990; Ortigues-Marty et al. 2003).

A decreased nutrient synchrony (i.e. increased circadian fluctuations in nutrient supply) also increased oxidative enzyme activities in RA in the current study (Table 2), but not in ST. Separating the availability of amino acids and glucose may have required temporarily high oxidative enzyme activities to provide energy for protein synthesis (see Ortigues-Marty et al. 2003) or to oxidize excessively available amino acids or glucose. As net protein utilization was unaffected and fat deposition was increased (Van den Borne et al. 2006b), temporarily increased rates of glucose and/or amino acid oxidation should be accompanied by decreased oxidation rates of oxidation during the remainder of the day.

It is noteworthy that nutrient synchrony only affected muscle enzyme activities in an oxidative muscle (RA), but not in a glycolytic muscle (ST). This corresponds with previous studies which demonstrated a higher response of oxidative (mitochondria-rich) than glycolytic muscles to nutrient supply (Cassar-Malek et al. 2004; Jurie et al. 2006).

\section{Effects of nutrient synchrony on muscle composition}

Intramuscular fat content was almost threefold higher in RA than in ST, which agrees with the generally described higher fat content in oxidative than in glycolytic muscles (Gondret et al. 1998; Hocquette et al. 2003). The increased intramuscular fat content in RA with decreasing nutrient synchrony corresponds to an increased whole body fat deposition in these calves (Van den Borne et al. 2006b) indicating that the extra fat is at least partly deposited in muscles. Intramuscular fat generally develops after abdominal, intermuscular and 
subcutaneous fat deposition (Vernon, 1981), which suggests that nutritional regulation of partitioning of fat into muscle is unlikely in relatively young animals (approximately 18 weeks of age). On the other hand, fat deposition in muscle may have been selectively stimulated by the increased glucose supply after a high lactose meal. Smith \& Crouse (1984) showed that glucose provides only $1-10 \%$ of the acetyl units to in vitro lipogenesis in subcutaneous adipose tissue of steers, but $50-75 \%$ of the acetyl units in the intramuscular adipocytes. This may be true for preruminants as well, thus providing an explanation for the effect of nutrient synchrony on intramuscular fat content of RA. However, care should be taken in extrapolating these results to the in vivo situation of preruminants, as they absorb much larger amounts of longchain fatty acids and monosaccharides (glucose and galactose) than mature ruminants.

The intramuscular glycogen content was higher in both muscles after the high protein diet than after the high lactose diet, but interpretation of this interaction between SYN and SEQ on glycogen content is complicated by its non-linearity. The lower glycogen content when protein and carbohydrate intakes are further separated may be explained by a lower insulin response in more asynchronously fed calves (T Vicari, JJGC Van den Borne, WJJ Gerrits, Y Zbinden and JW Blum, unpublished results). This corresponds with human studies in which the insulin response as well as muscle glycogen accumulation was higher after a mixed protein and carbohydrate meal than after a carbohydrate meal (Zawadzki et al. 1992; Van Loon et al. 2000), but does not explain the low muscle glycogen content at the most synchronous treatment treatments.

\section{Correlations within muscle}

Cytochrome-c-oxidase activity was positively correlated with muscle composition in RA (i.e. intramuscular fat) in the current study. This relationship between an oxidative enzyme and muscle fat content in RA seems paradoxical, but similar results were obtained in growing rabbits (Gondret et al. 2004) and steers (Hocquette et al. 2003). A high fat deposition and a high fatty acid oxidation can go together as the result of a high fatty acid flux. Although the fat intake with the two daily meals did not differ between treatments, the degree of nutrient synchrony may have (temporarily) increased the fatty acid flux by affecting the kinetics of fat digestion and/or the partitioning of fatty acids to individual tissues.

\section{Correlations between muscle enzyme activities and whole body energy metabolism}

In human subjects, positive correlations between muscle enzyme activities and $24 \mathrm{~h}$ heat production or sleeping metabolic rate were found (Zurlo et al. 1994; Doucet et al. 2003). In the present study, however, average whole body heat production was not correlated with enzyme activities in RA and ST. Our initial hypothesis that the decreased whole body heat production with decreasing nutrient synchrony is associated with decreased muscle oxidative enzyme activities therefore has to be rejected. Oxidative enzyme activity in RA 
Table 5. Pearson correlation coefficients between oxidative enzyme activities and muscle composition in $M$. Rectus Abdominis and whole body energy metabolism traits in heavy preruminant calves $(n 22)$

\begin{tabular}{|c|c|c|c|c|c|c|}
\hline Trait & CS & $\operatorname{cox}$ & CS:LDH & COX:LDH & Fat & Glycogen \\
\hline \multicolumn{7}{|l|}{ Average } \\
\hline Heat production & -0.06 & -0.33 & -0.22 & -0.42 & $-0.49^{\star}$ & -0.06 \\
\hline Activity related heat production & 0.04 & -0.41 & 0.06 & -0.29 & $-0.43^{\star}$ & 0.09 \\
\hline Activity corrected heat production & -0.09 & -0.20 & -0.28 & -0.36 & -0.37 & -0.11 \\
\hline \multicolumn{7}{|l|}{ Maximum } \\
\hline Heat production & 0.28 & -0.29 & 0.19 & $-0 \cdot 27$ & -0.35 & 0.08 \\
\hline Activity related heat production & $0.53^{\star \star}$ & -0.12 & $0.58^{\star \star}$ & -0.10 & -0.22 & 0.26 \\
\hline Activity corrected heat production & -0.12 & -0.26 & -0.27 & -0.39 & $-0.44^{\star}$ & -0.14 \\
\hline \multicolumn{7}{|l|}{ Amplitude } \\
\hline Heat production & $0.63^{\star *}$ & 0.08 & $0.66^{\star * *}$ & 0.10 & -0.08 & 0.16 \\
\hline Activity related heat production & $0.61^{\star *}$ & -0.14 & $0.58^{\star \star}$ & -0.11 & -0.20 & 0.19 \\
\hline Activity corrected heat production & -0.04 & -0.14 & -0.05 & -0.14 & -0.21 & -0.26 \\
\hline
\end{tabular}

$\mathrm{LDH}$, lactate dehydrogenase; COX, cytochrome-c-oxidase; CS, citrate synthase.

${ }^{\star} P<0.05 ;{ }^{\star \star} P<0.01 ;{ }^{\star \star \star} P<0.001$.

was positively correlated with the circadian maximum and amplitude of $\mathrm{H}_{\mathrm{act}}$ in growing calves. A similar correlation was found with $\mathrm{H}_{\mathrm{tot}}$, which can be explained by the high contribution of variation in $\mathrm{H}_{\text {act }}$ to variation in $\mathrm{H}_{\text {tot }}$.

The high feeding level in preruminant calves may explain why oxidative enzyme activity in muscle showed a better relationship with within-day variation in $\mathrm{H}_{\text {act }}$ than with average $\mathrm{H}_{\text {tot }}$. Apart from muscle, several other tissues contribute to whole body heat production. Feeding large amounts of nutrients results in a high diet-induced heat production predominantly caused by portal drained viscera and liver (Ortigues et al. 1995). This may also explain the different results in growing calves and non-growing man. The diet-induced heat production usually contributes for 30 to $35 \%$ to $\mathrm{H}_{\text {tot }}$ in growing farm animals (Collin et al. 2001; Le Bellego et al. 2001; Van Milgen et al. 2001), but only for 5 to $15 \%$ to $\mathrm{H}_{\text {tot }}$ in adult human subjects (Westerterp, 2004). Consequently, the overall contribution of $\mathrm{H}_{\text {act }}$ and muscle energy metabolism to average $\mathrm{H}_{\text {tot }}$ is likely to be higher in man than in calves. The individual housing conditions in the current study restricted the physical activity of calves, whereas calves under practical circumstances are housed in groups. Although group-housing only marginally increased $\mathrm{H}_{\text {act }}$ compared with individual housing as shown in pigs (Rijnen, 2003), this may have contributed to the lack of correlation between oxidative enzyme activity and $\mathrm{H}_{\text {tot }}$ in this study.

Oxidative enzyme activities in muscle were not correlated with the average $\mathrm{H}_{\text {act }}$ but only with the circadian fluctuations in $\mathrm{H}_{\text {act }}$ (maximum and amplitude) in preruminant calves. This may be explained by the measurement of enzyme activity, which truly reflects the maximum enzyme activity rather than the enzyme activity in vivo. Variation in fatty acid oxidation, for example, is not necessarily associated with variation in oxidative enzyme activities in muscle (Piot et al. 1998). Enzyme activities depend not only on the capacity of enzymes to convert substrates into new (co or end) products, but also on the availability of substrates. The availability of substrates for oxidative enzymes within a day is affected by nutrient supply, but also by particular energy requiring processes like physical activity. It can therefore be expected that the maximum oxidative enzyme activity is regulated by the kinetics of substrate availability rather than by the daily average substrate availability. Although the major aim of this study was to determine effects of variation in nutrient supply on muscle energy metabolism, it appeared that variation in $\mathrm{H}_{\mathrm{act}}$ was positively correlated with CS activity in RA.

The positive correlation between physical activity and CS activity in muscle corresponds with results obtained in man (Rimbert et al. 2004), rats (Spangenberg et al. 2005), pigs (Petersen et al. 1997) and steers (Jurie et al. 2006). Similarly, muscle CS activity was $23 \%$ higher in group-housed calves than in individually housed calves (Ortigues-Marty et al. 2003) which likely relates to increased physical activity. Previous studies have, however, not related the muscle enzyme activity to in vivo energy expenditure. Therefore, the current study is one of the first to relate CS activity in muscle to heat production associated with physical activity (and hence to contractile activity in muscle tissue).

\section{Conclusions}

From the results of the present study it was concluded that a decreased nutrient synchrony increased oxidative enzyme activity and intramuscular fat content in the oxidative muscle RA of preruminant calves. This indicates that the within-day distribution of macronutrient availability can affect muscle composition and properties which may have consequences for muscle function and meat quality. However, the decrease in whole body heat production with increasing separation of protein and lactose intake could not be explained by a decrease in oxidative enzyme activities in muscle.

In human subjects, muscle enzyme activities relate to whole body energy expenditure. Consequently, enzyme activities can be used as predictors for energy expenditure. Our data indicate that this relationship is present only for the activity associated component of energy expenditure in growing preruminant calves. Therefore, this relationship loses significance when subjects are fed at higher intake levels. Consequently, muscle enzyme activities are probably useless as an indicator for whole body energy expenditure in rapidly growing animals. 


\section{Acknowledgements}

The financial support of the Netherlands Organisation for Scientific Research (NWO), the Product Board Animal Feed, Orffa Nederland Feed BV and Tate \& Lyle is gratefully acknowledged. We thank Sven Alferink, Meijke Booij, Koos van der Linden (Wageningen University) and David Chadeyron (INRA) for their technical assistance.

\section{References}

Ansay M (1974) Muscular individuality in cattle: study of the enzymatic equipment of some muscles [in French]. Ann Biol Anim Biochim Biophys 14, 471-486.

Bradford MM (1976) A rapid and sensitive method for the quantification of microgram quantities of protein utilizing the principle of protein-dye binding. Anal Biochem 72, 248-254.

Brandstetter AM, Picard B \& Geay Y (1998) Muscle fibre characteristics in four muscles of growing male cattle. II. Effect of castration and feeding level. Livest Prod Sci 53, 25-36.

Brouwer E (1965) Report of sub-committee on constants and factors. In Energy Metabolism, pp. 441-443 [KL Blaxter, editor]. London, UK: Academic Press.

Carroll NV, Longley RW \& Roe JH (1955) The determination of glycogen in liver and muscle by use of anthrone reagent. $J$ Biol Chem 220, 583-593.

Cassar-Malek I, Hocquette JF, Jurie C, Listrat A, Jailler R, Bauchart D, Briand Y \& Picard B (2004) Muscle-specific metabolic, histochemical and biochemical responses to a nutritionally induced discontinuous growth path. Anim Sci 79, 49-59.

Collin A, Van Milgen J, Dubois S \& Noblet J (2001) Effect of high temperature and feeding level on energy utilization in piglets. $J$ Anim Sci 79, 1849-1857.

Cruywagen CW, Brisson GJ, Tremblay GF \& Meissner HH (1990) Effect of curd suppression in a milk replacer on physiological parameters in calves. II. Selected blood profiles. S Afr J Anim Sci 20, 239-243.

Cuvelier C, Cabaraux JF, Dufrasne I, Clinquart A, Hocquette JF, Istasse L \& Hornick JL (2006) Performance, slaughter characteristics and meat quality of young bulls from Belgian Blue, Limousin and Aberdeen Angus breeds fattened with a sugar-beet pulp or a cereal-based diet. Anim Sci 82, 125-132.

Doucet E, Tremblay A, Simoneau JA \& Joanisse DR (2003) Skeletal muscle enzymes as predictors of 24-h energy metabolism in reduced-obese persons. Am J Clin Nutr 78, 430-435.

Geelen SNJ, Blázquez C, Geelen MJH, Sloet van OldruitenborghOosterbaan MM \& Beynen AC (2001) High fat intake lowers hepatic fatty acid synthesis and raises fatty acid oxidation in aerobic muscle in Shetland ponies. Br J Nutr 86, 31-36.

Gerrits WJJ, Dijkstra J, Verdonk JMAJ, Beelen GM \& Boer H (1999) Effects of ammonia and starch infusion in the colon of preruminant calves. The VIIIth International Symposium on Protein Metabolism and Nutrition 55.

Gondret F, Hocquette JF \& Herpin P (2004) Age-related relationships between muscle fat content and metabolic traits in growing rabbits. Reprod Nutr Dev 44, 1-16.

Gondret F, Lebas F \& Bonneau M (2000) Restricted feed intake during fattening reduces intramuscular lipid deposition without modifying muscle fiber characteristics in rabbits. J Nutr 130, 228-233.

Gondret F \& Lebret B (2002) Feeding intensity and dietary protein level affect adipocyte cellularity and lipogenic capacity of muscle homogenates in growing pigs, without modification of the expression of sterol regulatory element binding protein. J Anim Sci 80, 3184-3193.

Gondret F, Mourot J \& Bonneau M (1998) Comparison of intramuscular adipose tissue cellularity in muscles differing in their lipid content and fiber type composition during rabbit growth. Livest Prod Sci 54, 1-10.

Guilloteau P, Toullec R \& Grongnet JF (1986) Digestion of milk, fish and soya-bean protein in the preruminant calf: Flow of digesta, apparent digestibility at the end of the ileum and amino acid composition of ileal digesta. Br J Nutr 55, 571-592.

Helge JW \& Kiens B (1997) Muscle enzyme activity in humans: role of substrate availability and training. Am J Physiol 272, R1620-R1624.

Hocquette JF, Jurie C, Ueda Y, Boulesteix P, Bauchart D \& Pethick DW (2003) The relationship between muscle metabolic pathways and marbling of beef. In Progress in Research on Energy and Protein Metabolism, EAAP publication 109, 513-516 [WB Souffrant and CC Metges editors]. Rostock-Warnemünde, Germany: Wageningen Academic Publishers, The Netherlands.

Hocquette JF, Ortigues-Marty I, Pethick D, Herpin P \& Fernandez X (1998) Nutritional and hormonal regulation of energy metabolism in skeletal muscles of meat-producing animals. Livest Prod Sci 56, 115-143.

International Organization for Standardization (1999) Animal feeding stuffs. Determination of fat content. ISO 6492. Geneva, Switzerland: International Organization for Standardization.

Jurie C, Ortigues-Marty I, Picard B, Micol D \& Hocquette JF (2006) The separate effects of the nature of diet and grazing mobility on metabolic potential of muscles from Charolais steers. Livest Sci 104, 181-192.

Labarca C \& Paigen K (1980) A simple rapid and sensitive DNA assay procedure. Anal Biochem 102, 344-352.

Le Bellego L, Van Milgen J, Dubois S \& Noblet J (2001) Energy utilization of low-protein diets in growing pigs. J Anim Sci 79, $1259-1271$.

Ortigues-Marty I, Hocquette JF, Bertrand G, Martineau C, Vermorel M \& Toullec R (2003) The incorporation of solubilized wheat proteins in milk replacers for veal calves: effects on growth performance and muscle oxidative capacity. Reprod Nutr Dev 43, $57-76$.

Ortigues I, Martin C, Durand D \& Vermorel M (1995) Circadian changes in energy expenditure in the preruminant calf: whole animal and tissue level. J Anim Sci 73, 552-564.

Petersen JS, Henckel P, Maribo H, Oksbjerg N \& Sørensen MT (1997) Muscle metabolic traits, post mortem-pH-decline and meat quality in pigs subjected to regular physical training and spontaneous activity. Meat Sci 46, 259-275.

Pethick DW \& Rowe JB (1996) The effect of nutrition and exercise on carcass parameters and the level of glycogen in skeletal muscle of Merino sheep. Aust J Agric Res 47, 525-535.

Petit HV, Ivan M \& Brisson GJ (1988) Digestibility and blood parameters in the preruminant calf fed a clotting or a nonclotting milk replacer. J Anim Sci 66, 986-991.

Piot C, Veerkamp JH, Bauchart D \& Hocquette JF (1998) Contribution of mitochondria and peroxisomes to palmitate oxidation in rat and bovine tissues. Comp Biochem Physiol B 121, 185-194.

Rijnen MMJA (2003) Energetic utilization of dietary fiber in pigs. PhD Thesis, The Netherlands: Wageningen University.

Rimbert V, Boirie Y, Bedu M, Hocquette JF, Ritz P \& Morio B (2004) Muscle fat oxidative capacity is not impaired by age but by physical inactivity: association with insulin sensitivity. FASEB J 18, 737-739.

Shepherd D \& Garland PB (1969) Citrate synthase from rat liver. Methods Enzymol 13, 11-16.

Smith SB \& Crouse JD (1984) Relative contributions of acetate, lactate and glucose to lipogenesis in bovine intramuscular and subcutaneous adipose tissue. $J$ Nutr 114, 792-800.

Spangenberg EMF, Augustsson H, Dahlborn K, Essén-Gustavsson B \& Cvek K (2005) Housing-related activity in rats: Effects on body weight, urinary corticosterone levels, muscle properties and performance. Lab Anim 39, 45-57. 
Van den Borne JJGC, Verstegen MWA, Alferink SJJ, Giebels RMM \& Gerrits WJJ (2006a) Effects of feeding frequency and feeding level on nutrient utilization in heavy preruminant calves. $J$ Dairy Sci 89, 3578-3586.

Van den Borne JJGC, Verstegen MWA, Alferink SJJ, Van Ass FHM \& Gerrits WJJ (2006b) Synchronizing the availability of amino acids and glucose decreases fat retention in heavy preruminant calves. J Nutr 136, 2181-2187.

Van Es AJH, Nijkamp HJ, Van Weerden EJ \& Van Hellemond KK (1967) Energy, carbon and nitrogen balance experiments with veal calves. In Energy Metabolism of Farm Animals, pp. 197-201 [KL Blaxter, J Kielanowski and G Thorbek, editors]. Newcastle-upon-Tyne, UK: Oriel Press.

Van Hinsberg VWM, Veerkamp JH \& Bookelman H (1978) Palmitate oxidation by rat skeletal muscle mitochondria. Comparison of polarographic and radiochemical experiments. Arch Biochem Biophys 190, 762-771.

Van Loon LJC, Saris WHM, Kruijshoop M \& Wagenmakers AJM (2000) Maximizing postexercise muscle glycogen synthesis: carbohydrate supplementation and the application of amino acid or protein hydrolysate mixtures. Am J Clin Nutr 72, 106-111.
Van Milgen J, Noblet J \& Dubois S (2001) Energetic efficiency of starch, protein and lipid utilization. J Nutr 131, 1309-1318.

Verdonk JMAJ, Gerrits WJJ, Beelen GM \& Jansman AJM (1999) Effect of protein source on portal nutrient fluxes in pre-ruminant calves. In The VIII H, International Symposium on Protein Metabolism and Nutrition, pp. 47 [GE Lobley, A. White and JC MacRae, editors]. Aberdeen, Uk: Wageningen Press, The Netherlands.

Vernon RG (1981) Lipid metabolism in the adipose tissue of ruminants. In Lipid metabolism in ruminant animals, pp. 279-362 [WW Christie, editor]. Oxford, UK: Pergamon Press.

Wenk C \& Van Es AJH (1976) A method for determining the energy expenditure associated with physical activity in growing chickens [in German]. Schweiz Landwirtsch Monatsh 54, 232.

Westerterp KR (2004) Diet induced thermogenesis. Nutr Metab 1, 1-5.

Zawadzki KM \& Yaspelkis 3rd BB, Ivy JL (1992) Carbohydrate-protein complex increases the rate of muscle glycogen storage after exercise. J Appl Physiol 72, 1854-1859.

Zurlo F, Nemeth PM, Choksi RM, Sesodia S \& Ravussin E (1994) Whole-body energy metabolism and skeletal muscle biochemical characteristics. Metabolism 43, 481-486. 